\title{
Identification and characterization of a new Halomicronema species (Cyanobacteria) isolated from the Mediterranean marine sponge Petrosia ficiformis (Porifera)
}

\author{
Carmela CARoppo ${ }^{*}$, Patrizia Albertano ${ }^{2}$, Laura Bruno 2 , Mariarosa Montinari ${ }^{3}$, \\ Marco Rizzi ${ }^{4}$, Giovanni Vigliotta ${ }^{5} \&$ Patrizia Pagliara $^{3}$ \\ ${ }^{1}$ Institute for Coastal Marine Environment, Unit of Taranto, National Research Council, Via Roma, 3 - 74100, \\ Taranto, Italy; * Corresponding author e-mail: carmela.caroppo@iamc.cnr.it, tel.: +39 994545211 , fax: +39 99 \\ 4545215 \\ ${ }^{2}$ Laboratory of Biology of Algae, Department of Biology, University of Rome "Tor Vergata”, Italy \\ ${ }^{3}$ DiSTeBA, Department of Biological and Environmental Sciences and Technologies, University of Salento, Lecce, \\ Italy \\ ${ }^{4}$ Azienda Ospedaliera Policlinico di Bari, Italy \\ ${ }^{5}$ Department of Chemistry, University of Salerno, Fisciano (Salerno), Italy
}

\begin{abstract}
A filamentous cyanobacterium (strain ITAC101) isolated from a Mediterranean sponge (Petrosia ficiformis) was characterized by a combined phenotypic and genetic approach. Morphological and ultrastructural observations were performed along with growth measurements and pigment characterization. The molecular phylogenetic analyses were based on the sequencing of the $16 \mathrm{~S}$ rRNA gene. In culture conditions, strain ITAC101 is moderately halophilic and grew in the range $0.3-7.6 \%(\mathrm{w} / \mathrm{v})$ salinity with the optimum at $3.6 \%$. Cell dimensions, thylakoid arrangement and pigment composition of this cyanobacterium fit the Halomicronema genus description, and phylogenetic analyses evidenced $99.9 \%$ similarity with another strain endolithic in tropical corals. The new Halomicronema metazoicum species was established including the two cyanobacteria associated to marine animals.
\end{abstract}

Key words: cyanobacteria, Leptolyngbya, marine sponge, Mediterranean Sea, polyphasic approach,16S rRNA

\section{Introduction}

The association between cyanobacteria and sponges is a well known and largely studied phenomenon and has been confirmed in at least 26 Demospongiae and 17 Calcarea families (CARpenter 2002; Diaz et al. 2007; Zhu et al. 2008). This mutually beneficial association is thought to be one of the oldest microbe-metazoan interactions, and is speculated to have dominated over hard corals during periods of the Paleozoic and Mesozoic (TAYLOR et al. 2007). Indeed, in a number of marine sponges, single-celled and filamentous cyanobacteria having both extracellular and intra-cellular localization (RÜTZLER 1990; WILKINSON 1992) are frequently found. In this association, the involved cyanobacterial species mainly belong to the genera Synechocystis (LARKUm et al. 1988), Aphanocapsa (FELDMANN 1933), Oscillatoria (WILKINSON 1992; THACKeR
\& STARNes 2003), Anabaena (LARKUM 1999), Cyanobacterium (WeBB \& MAAS 2002) and Synechococcus (Hentschel et al. 2002). Other cyanobacteria associated to sponges include Prochlorococcus (STEINDLER et al. 2005) and two, so far unnamed, symbionts of Mycale hentscheli and Cymbastela marshae (Hentschel et al. 2006).

Actually, the knowledge of the diversity and the ecological role of cyanobacteria living in association with sponges is in its infancy, and molecular and biochemical techniques are greatly expanding the information on their taxonomy and phylogeny, particularly in case of culturable microorganisms (UsHER et al. 2004). At present, the relevance of culturing cyanobacteria derives from their ability to produce bioactive natural compounds for biotechnological application (MOORE et al. 1988; Sivonen \& BöRner 2008; GERÇE et al. 2009). Moreover, the chemical 
structures of over 13,000 novel compounds from marine organisms have been already determined and their potential use in pharmaceutics widely considered (FENICAL 1997).

Recently, eight cyanobacterial strains were isolated from themarine sponge Petrosiaficiformis, and among them, the strain ITAC101, firstly assigned to the genus Leptolyngbya. This species resulted particularly interesting because showed haemolytic activity and influenced brine shrimp vitality and sea urchin development (Pagliara \& CAROPPO 2010, 2011). These preliminary findings encouraged further investigations to characterize and identify the strain.

The taxonomic classification of nonheterocystous, thin filamentous cyanobacteria having trichomes $<3 \mu \mathrm{m}$ is controversial. These cyanobacteria have been previously assigned to the genus Phormidium (GeITLER 1932) according to the botanical code, and to the Lyngbyal Plectonema/Phormidium-group B (RIPPKA et al. 1979) according to the bacteriological system. Lately, they have been included in the genus Leptolyngbya by ANAGNOSTIDIS \& KOMÁREK (1988) and accordingly described in the BERGEY's manual of systematic bacteriology (CASTENHOLZ $\&$ W ATERBURY 1989). Indeed, the combined use of molecular and traditional techniques (WILMOTTE 1994; Garcia-Pichel et al. 1998; Nübel et al. 2000) subsequently revealed that cyanobacteria with Phormidium-like morphologies do not form a monophyletic group (GIOvANNONI et al. 1988).

Among the Phormidium-like cyanobacteria, a new genus of non-heterocystous, thin filamentous species has been recently described as Halomicronema excentricum by ABED and coauthors (2002a). This cyanobacterium has been firstly isolated from benthic microbial mats in a hypersaline pond of the Solar Lake (Sinai, Egypt), and also found in Camargue (France) (FourÇANS et al. 2004), in a heavily polluted site of a coastal stream in Palestine (ABED et al. 2002b) and in the Arabian Gulf (ABED et al. 2006). Probably, the filamentous cyanobacterium inhabiting the skeleton of Goniastrea aspera, a massive reefbuilding coral, also belongs to Halomicronema genus (YAMAZAKI et al. 2006; 2008a).

Theaimofthis paperwas the characterization and the proper identification by a polyphasic approach of the strain ITAC101 isolated from the sponge Petrosia ficiformis. By combining morphological, ultrastructural, physiological, biochemical and molecular studies, the strain was analyzed with light and transmission electron microscopy, its growth measured at varying salinity, pigment content characterized and all these phenotypic traits compared to the results obtained by molecular taxonomy based on $16 \mathrm{~S}$ rRNA gene sequence analysis (KOMÁREK 2005).

\section{Materials and methods}

\section{Strain origin and growth conditions}

Specimens of Petrosia ficiformis were collected from the Gulf of Taranto (Northern Ionian Sea, Mediterranean Sea), at the Porto Cesareo station (E $17^{\circ} 55^{\prime}$ 50", $\mathrm{N} 40^{\circ} 10^{\prime} 40^{\prime}$ ), using SCUBA at depths between 0.5 and $10 \mathrm{~m}$, in October 2008. Sea temperature, $\mathrm{pH}$ and salinity were simultaneously measured by an Idronaut Ocean Seven 501 multiprobe. During the study period water temperature ranged from 19.70 to $21.80{ }^{\circ} \mathrm{C}$, salinity from 3.84 to $3.87 \%$ and $\mathrm{pH}$ from 8.05 to 8.10 .

The sponges were transferred to the laboratory, rinsed with filtered sea water and cut into small pieces. Each piece was pressed through a nylon mesh $(100 \mu \mathrm{m}$ pore size) to obtain a suspension of single cells. This suspension was centrifuged, then filtrated by using a $100 \mu \mathrm{m}$ net and inoculated both on solid and liquid $\mathrm{MN}$ medium enriched with $\mathrm{B}_{12}$ vitamin $\left(5 \mu \mathrm{g} . \mathrm{l}^{-1}\right)$ (RIPPKA et al. 1979). Solid media were prepared by adding $1 \%$ (w/v) of agar to liquid MN medium. Cycloheximide (100 mg. $1^{-1}$ ) was added to all cultures to prevent the growth of eukaryotic contaminants. The cultures were incubated at $26.0 \pm 1.0{ }^{\circ} \mathrm{C}$ under white fluorescent light at a photosynthetic photon flux density of 20 $\mu$ mol.photon. $\mathrm{m}^{-2} \cdot \mathrm{s}^{-1}$ (KANA \& GLIBERT 1987) and a light/dark cycle of 12:12 hours. Monospecific cultures with extremely thin filaments were isolated and further purified by successive transfers. Axenic culture was obtained after repeated self-isolation on agar (CASTENHOlz 1988). To assess the purity of the strain, the samples were stained with 4'-6-diamidino2-phenylindole dihydrochloride (DAPI, Sigma) and observed under an epifluorescence microscope.

The axenic strain ITAC101 is presently deposited and maintained at the Institute TAranto $\mathrm{Cnr}$ - ITAC culture collection.

\section{Growth measurements}

Cultures were grown in $250 \mathrm{ml}$ Erlenmeyer flasks, containing $100 \mathrm{ml}$ of $\mathrm{MN}$ medium at $0,1.8,3.6,4.4,7.2$, 9.0 and $10.8 \%$ salinity under the same temperature and light conditions reported above. The different salinity concentrations, from hyposaline to hypersaline, were obtained by adding appropriate amounts of distilled water or $\mathrm{NaCl}$ to the natural seawater $(3.8 \%)$.

Growth was followed in triplicate cultures during 10 days and measured by monitoring chlorophyll- $a$ (Chl-a) concentration as biomass indicator. At the end of the experiments, all the cultures were kept for 
additional 2 months in the same conditions in order to check slow growth rates and long-term ability to survive under nutrient starvation.

To evaluate $\mathrm{Chl}-a$ content triplicate samples ( $1 \mathrm{ml}$ of cell suspension) from each salinity condition were collected at the indicated times, washed twice with ultrapure sterile water and harvested at 12,000 $\times$ $g$ for $10 \mathrm{~min}$. Extraction was performed in $1 \mathrm{ml}$ of $90 \%$ (v/v) methanol at $25^{\circ} \mathrm{C}$ for $15 \mathrm{~min}$ in the dark, followed by centrifugation at $12,000 \times g$ for $10 \mathrm{~min}$. Absorbance of the supernatant, was determined at $663 \mathrm{~nm}$ using a spectrophotometer (Beckman Coulter DU $800 \mathrm{UV} /$ Vis, Spectrometer) (FIORE et al. 2000). Comparison of biomass reached at the stationary phase was done by measuring the absorbance of Chl- $a$ for each salinity condition. The Chl-a content was estimated using the equation: $C\left(\mu \mathrm{g} \cdot \mathrm{ml}^{-1}\right) \times \mathrm{OD}_{663} \times 12.7($ MeEKs \& Castenholz 1971).

\section{Confocal laser scanning microscopy (CLSM)}

For confocal analysis the samples were processed alive. The cells were directly placed on a microscope slide, sealed with cover slip and observed using a $488 \mathrm{~nm}$ Argon laser line of a C1 Nikon confocal laser scanning unit coupled to a Nikon TE300 microscope with a $100 \times / 1.30$ oil objective (Nikon, Japan). For pigment fluorescence (autofluorescence) an excitation filter at $568 \mathrm{~nm}$ (emission at $>590 \mathrm{~nm}$ ) was used.

\section{Transmission electron microscopy}

Samples of growing cultures were prepared for electron microscopy. Specimens were fixed with $2.5 \%$ glutaraldehyde in cacodylate buffer $0.1 \mathrm{M}, \mathrm{pH} 7.2$, and post-fixed with $1 \%$ osmium tetroxide in the same buffer. Then samples were dehydrated in a graded alcohol series, embedded in Spurr's resin, and sectioned at 90 $\mathrm{nm}$ with an ultracut (Leica Microsystem, Germany). The sections were stained with $2 \%$ uranyl acetate and lead citrate and examined in a Zeiss EM 910 electron microscope operating at $60 \mathrm{kV}$.

\section{Pigment analysis}

Pigment analysis involved chromatographic and spectrophotometric characterization and quantification of chlorophylline pigments, carotenoids and phycobiliproteins of the strain ITAC101. Samples of about $50 \mathrm{mg}$ dry weight were thoroughly washed with distilled water to remove medium and then suspended in either $3 \mathrm{ml}$ of absolute acetone for the extraction of chlorophylline pigments and carotenoids or in $3 \mathrm{~mL}$ of $0.01 \mathrm{M}$ phosphate buffer, $\mathrm{pH} 7.0$, plus $0.15 \mathrm{M} \mathrm{NaCl}$ for the extraction of phycobiliproteins. Samples were sonicated for $4 \mathrm{~min}$ in ice-bath, centrifuged for $20 \mathrm{~min}$ at $15,000 \mathrm{~g}$ and filtered through $0.45 \mu \mathrm{m}$ cellulose filters. Profile of the chlorophylline pigments and carotenoids in the crude extract was obtained by HPLC-DAD on a Agilent 1100 binary system with a Luna C18(2)
250 x $4.6 \mathrm{~mm} 5 \mu \mathrm{m}$ analytical column (Phenomenex, St. Torrents, USA ), following the protocol of AIRS et al. (2001). Peaks were identified on the basis of the retention time and absorbance spectra obtained using a Beckman Coulter DU 800 UV/Vis spectrophotometer. Quantification of Chl- $a$ and some major carotenoids was carried out by Gauss Peak spectra analysis (KÜPPER et al. 2007) on the absorbance spectrum in the range $350-700 \mathrm{~nm}$. After the recording of absorbance spectra of crude phycobiliproteins extracts, quantification of phycoerythrin, phycocyanin and allophycocyanin was obtained using the equations of BENNET \& BOGORAD (1972).

\section{DNA extraction}

DNA extraction was performed by a modified method previously described by Lotті et al. (1996). Briefly, fresh cells were harvested during exponential phase by centrifugation $\left(11,000 \times \mathrm{g}\right.$ for $20 \mathrm{~min}$ at $\left.15^{\circ} \mathrm{C}\right)$ and washed with TEN-25 buffer ( $25 \mathrm{mM}$ Tris/ $\mathrm{HCl}, 25 \mathrm{mM}$ EDTA, $100 \mathrm{mM} \mathrm{NaCl}, \mathrm{pH} 8$ ). The pellets were kept frozen at $-20{ }^{\circ} \mathrm{C}$ until use. To obtain spheroplasts, the cells were suspended in TEN buffer $(10 \mathrm{mM}$ Tris/ $\mathrm{HCl}$, $1 \mathrm{mM}$ EDTA, $100 \mathrm{mM} \mathrm{NaCl}, \mathrm{pH}$ 8), and incubated with $100 \mu \mathrm{g} . \mathrm{ml}^{-1}$ proteinase $\mathrm{K}$ and $100 \mu \mathrm{g} . \mathrm{ml}^{-1}$ lysozyme. The suspension was incubated for $60 \mathrm{~min}$ at $4{ }^{\circ} \mathrm{C}$ under slow shaking. Lyses of spheroplasts was achieved by adding 2\% SDS (w/v) and incubating for 90 to $120 \mathrm{~min}$ at $4{ }^{\circ} \mathrm{C}$ under gentle shaking. The subsequent extraction and purification was performed by phenol-chloroform and isoamylic alcohol $(25: 24: 1)$ according to standard procedures (SAmBrooK \& RuSSEL 2001). $40 \mu \mathrm{g} . \mathrm{ml}^{-1}$ of ribonuclease A were used to remove RNA. The DNA was then precipitated with ethanol, collected with a glass rod and re-suspended in TE buffer (10 mM Tris/ $\mathrm{HCl}, 1 \mathrm{mM}$ EDTA, pH 8). The quality and quantity of DNA was analyzed by electrophoresis on $0.8 \%$ agarose gel and spectrophotometric analysis (MANIATIS et al. 1982).

\section{S rRNA Gene Sequence Analysis}

The gene coding for 16S rRNA subunit was subjected to polymerase chain reaction (PCR) amplification using the cyanobacteria-specific universal primers CIANO1-F (5'-CTTAACACATGCAAGTCGAAC-3') and CIANO4-R (5'-CTCCTCCACAAGGGTTGGA GTAAC-3'), complementary to Synechococcus sp. PCC7001 16S rRNA (GenBank accession no. AB015058) sequence position 21-42 and 1356-1379 respectively. Primers were constructed by CLUSTAL W program from European Bioinformatics Institute (http:// www.ebi.ac.uk/), for multiple sequence alignments of cyanobacterial sequences, and by Probe Match tool of the Ribosomal Database Project II (RDP) (http:// rdp.cme.msu.edu/), for specificity evaluation. PCR, reactions were performed in a $25 \mu$ l reaction mixture containing approximately $100 \mathrm{\eta g}$ of genomic DNA and $0.5 \mathrm{U}$ of Taq polymerase (Amersham, Pharmacia), 
according to the manufacturer's instructions, in a Perkin-Elmer GeneAmp PCR System 9600 (Perkin Elmer, USA) as follows: 5 min initial denaturation at 94 ${ }^{\circ} \mathrm{C}$, followed by 35 cycles of denaturation at $94{ }^{\circ} \mathrm{C}$ for $1 \mathrm{~min}$, annealing at $55^{\circ} \mathrm{C}$ for $1 \mathrm{~min}$ and extension at 72 ${ }^{\circ} \mathrm{C}$ for $1.45 \mathrm{~min}$. The final extension was set at $72{ }^{\circ} \mathrm{C}$ for $7 \mathrm{~min}$. PCR products were separated by electrophoresis in $1 \%$ agarose gels in TAE buffer ( $40 \mathrm{mM}$ Tris-acetate, 1 mM EDTA, $\mathrm{pH}$ 8.0) and recovered by using the Qiaex II DNA purification kit (QIAGEN). PCR products were subjected to DNA sequencing of both strands as a service by MWG Biotech Custom Sequencing Service (Germany) utilizing primer Ciano1-F/Ciano4-R and Com1-F (5'-CAGCAGCCGCGGTAATAC-3') / Com2-R (5'-CCGTCAATTCCTTTGAGTTT-3'), annealing position 519-536 and 927-908, respectively, of $E$. coli $16 \mathrm{~S}$ rRNA gene (LANE et al. 1985). Processing of the DNA sequences was performed with the software GeneJockey Sequence Processor (published and distributed by Biosoft).

\section{Phylogenetic analysis}

The 16S rRNA gene sequence of the isolated strain (1358 nucleotides) was first analyzed by a similarity search using the BLAST function of GenBank at the National Center NCBI electronic site and the Seq Match tool of the Ribosomal Database Project II (http://www.ncbi.nlm.nih.gov/ and http://rdp.cme.msu. edu/, respectively). For phylogenetic analysis were considered 16S rRNA gene sequences of cyanobacteria longer than 1000 nucleotide deposited in GenBank and RDP databases and multiple sequence alignments were conducted using the CLUSTAL W program from European Bioinformatics Institute (http://www.ebi. ac.uk/). To infer phylogenetic relationships among the taxa, different analytical methods were employed. Maximum-parsimony and distance trees were generated using a heuristic search constrained using the PAUP* 4.0 b10 software package (SwOFFORD 2001). A maximum-likelihood tree was constructed using the PAUP* software with the computation of likelihood scores obtained with PHYML by JMODELTEST 0.1.1 (PosAdA 2008) with the estimation of the GTR $+\mathrm{I}+\mathrm{G}$ model. The robustness of the inferred phylogenies was determined by bootstrap analysis based on 1000 resamplings of data. The Bayesian inference (BI) was performed using MRBAYES 215 version 3.0 (RONQUIST \& Huelsenbeck 2003). The substitution model was the $\mathrm{GTR}+\mathrm{I}+\mathrm{G}$. Bayesian analysis was performed using four search chains for 1000000 generations, sampling trees every 100 generation. The first 1000 trees were discarded as burn-in. Parameter 220 stability was estimated by plotting log-likelihood values against generation time, and a consensus tree with posterior probabilities (PP) was then generated.

The 16S rRNA gene sequence was deposited in the Gen Bank database under accession number GU220365.

\section{Results}

\section{Morphology}

The axenic culture of the filamentous cyanobacterium ITAC101 was obtained after isolation from the sponge $P$. ficiformis. In liquid culture, filaments appeared as deep-green macroscopic aggregates covering the walls of the culture vessel. On solid media, colonies did not show gliding motility or phototaxis towards a light source, also after a long term exposition.

The filament sheath was colourless, very thin, firm and distinct (Fig. 1a). A calyptra was evident at the end of most filaments (Fig. 1b). Filaments were about $1 \mu \mathrm{m}$ wide with slight constrictions at the cross-wall, better visible in CLSM (Fig. 1c). Cells $0.8-1.0 \mu \mathrm{m}$ in diameter were always longer than wide and their length usually ranged from 3 to $6 \mu \mathrm{m}$. Seldom, shorter (around $2 \mu \mathrm{m}$ ) and longer (up to $8 \mu \mathrm{m}$ ) cells have been observed in the apical and sub-apical zone of the trichomes. Reproduction occurred by fragmentation in two-three celled hormogonia.

TEM analysis (Fig. 2) evidenced the fibrillar and compact structure of the sheath and the presence of cell wall constrictions (Figs 2a, d). Pores were present on cell walls and septa. Three peripheral thylakoids run in the peripheral cytoplasm, concentrically arranged around the long axis of the trichome (Fig. 2b). Phycobilisomes were not observed on the thylakoidal membranes. Polyhedral bodies (carboxysomes), polyphosphate and cyanophycin granules, and lipid inclusions (Figs 2b, c, d) were present in the nucleoplasm along with DNA fibrils and polyribosomes while gas vesicles were never observed.

\section{Growth rates at varying salinity}

In laboratory, significant growth was observed up to $4.4 \%$ salinity, with the optimal condition around $3.6 \%$ (Fig. 3). Growth rates at $0.3 \%, 1.8 \%, 3.6 \%$ and $4.4 \%$ were respectively $0.21,0.26,0.39$ and 0.19 generations per day. At $7.2 \% \mathrm{NaCl}$ growth decreased to 0.16 after 10 days and the culture remained viable for the next two months. After four days at $9.0 \%$ and $10.8 \% \mathrm{NaCl}$ cultures died.

\section{Pigment analysis}

Strain ITAC101 has deep-green trichomes due to a complex profile of lipophilic pigments, as evidenced by the HPLC chromatogram comprising up to 43 detectable peaks (Fig. 4). The majority of the HPLC peaks were due to the homologues of few 

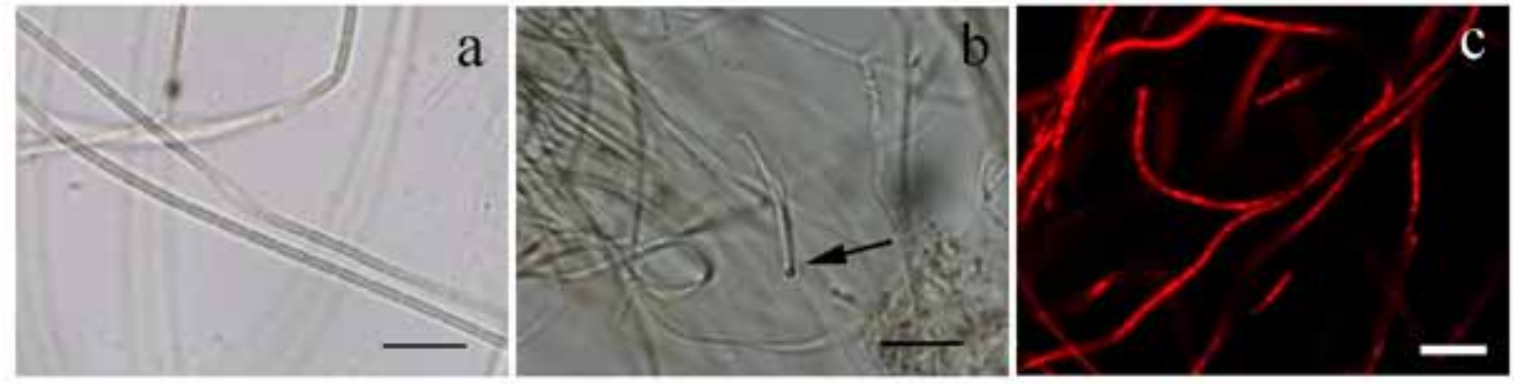

Fig. 1. Light micrographs (a, b scale bar $5 \mu \mathrm{m}$ ) and CLSM image (c, scale bar $10 \mu \mathrm{m}$ ) of Halomicronema ITAC101.

basic pigments: chlorophyllide- $a$, chlorophyll $-a$, pheophytin- $a$, zeaxanthin, $\beta$-cryptoxanthin and canthaxanthin. Chlorophyll- $a$ was largely the major photosynthetic pigment, representing the $53.2 \%$ of the total lipophylic pigment content. Zeaxanthin and $\beta$-cryptoxanthin accounted for the $49.4 \%$ and $36.4 \%$ respectively of the total carotenoids, the rest being represented by canthaxanthin $(14.3 \%)$. Some cyanobacterial biomarkers, like echinenone andmyxoxanthophyll, were totally absent and other common carotenoids, such as $\beta$-carotene and neoxanthin were found only in trace.

The absorption spectra of phycobiliprotein crude extracts showed major peaks in the visible range at 560 and 615, and shoulder at 650 and $680 \mathrm{~nm}$ (Fig. 5). Phycoerythrin accounted for the $60 \%$ of total phycobiliproteins, followed by phycocyanin $(29.0 \%)$ and allophycocyanin $(11.0 \%)$.

\section{Molecular characterization}

The strain ITAC101 was characterized by 16S rRNA gene analysis and its phylogenetic relationships with other 56 strains of cyanobacteria, available in database, represented by a maximum-likelyhood tree (Fig. 6). Strain ITAC101 showed $99.9 \%$ pairwise sequence identity with Halomicronema sp., strain Goniastrea-1 (GenBank accession number AB257773) isolated from the skeleton of the reef-building coral Goniastrea aspera (YAMAZAKI et al. 2008a). The two strains clustered together in a different clade of that formed by the type species $H$. excentricum (GenBank accession number AF320093), isolated from a man-made hypersaline pond (ABED et al. 2002a), and other Halomicronema strains isolated from benthic microbial mats in the Shark Bay, SCyano39 and SCyano40 (Allen et al., unpublished). The clades were resolved with high PP (1.00) in BI and high bootstrap values $100 \%$ in ML analyses. The pairwise sequence identities shown by ITAC101 and the other Halomicronema strains considered in this study ranged from 94.6 to $94.8 \%$, while with genera of thin filamentous cyanobacteria such as Leptolyngbya, Limnothrix and Geitlerinema were lower than 92\%.

\section{Discussion}

This is the first report of a Halomicronema species living in association with a marine sponge and the first record of this genus for the Mediterranean Sea. A complex microbial community was recently described in association to Petrosia ficiformis, in which cyanobacteria are represented by coccoid and filamentous species (Pagliara \& CAROPPO 2011). Based on morphology, some of the latter species have been previously ascribed to the genus Leptolyngbya because of their very thin filaments (PAgliara \& CARoppo 2010). However, the strain ITAC101 was for the first time characterized in axenic culture after isolation from the sponge Petrosia ficiformis, and this allowed its proper characterization and identification. Up to date, only heterotrophic bacterial cultures have been obtained from sponges (Hentschel et al. 2001; LAFI et al. 2005). The culturing of microorganisms isolated from sponges is a necessary step not only for the assessment of the physiological and biochemical features, but also to analyze the ability to produce secondary metabolites. A collection of microbial isolates makes the screening for biopharmaceuticals more feasible on a large scale and possible the scale-up of an in vitro production with no need to culture the metabolite sponge tissue itself (HAYGOOD et al. 2000).

Among cyanobacterial symbionts of the Mediterranean sponge Petrosia ficiformis, Aphanocapsa feldmannii (FeLdMANn 1933) has been the best described (USHER 2008). This 
coccoid species is responsible for the red colour of the host living in dim light environments. Previous phylogenetic analyses clarified the identity of this cyanobacterium and demonstrated that it belongs to the Synechococcus genus (UsHER et al. 2004). This supported the need of using microscopy in combination with molecular studies since, the description of microbial species without genetic support is criticised by numerous authors. Accordingly, molecular techniques involving DNA sequencing (CASAMATTA et al. 2005; GKelis et al. 2005; Comte et al. 2007; BRUNo et al. 2009) are presently used to investigate evolutionary relationships within cyanobacteria. Therefore, the idea that polyphasic approach is indispensable to identify cyanobacterial strains at genus as well as at species level (e.g. MARQuARDT \& PALINSKA 2007) has been supported also by our analyses.

The combination of morphological, physiological, biochemical and molecular data obtained for the strain ITAC101 allows its inclusion in the Halomicronema genus, family Pseudanabaenaceae.

The immobility of the benthic marine, non-heterocystous, very thin filaments, the cylindrical trichomes $<1 \mu \mathrm{m}$ wide, and the peripheral arrangement of thylakoids parallel to the plasma membrane are in agreement with the diagnostic features of the genus Halomicronema

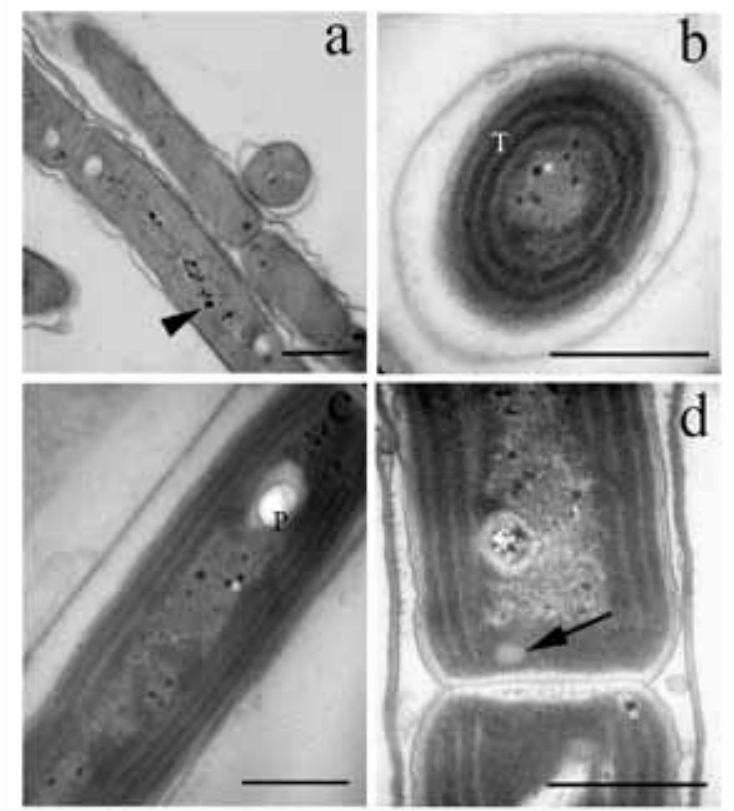

Fig. 2. TEM micrographs of Halomicronema ITAC101. Note the peripheral (b) and parallel (c) disposition of thylakoids; lipid droplet (asterisk), cyanophycin granules, and carboxysomes (arrows) were also observed in the cytoplasm. Scale bar $1 \mu \mathrm{m}$ (a) and $0.5 \mu \mathrm{m}$ (b, c; d)
Abed, Garcia-Pichel et Hernandez-Mariné. The presence of a colourless, firm though thin, fibrillar sheath and cell wall constrictions, the length to width ratio higher than $3-2: 1$, the symmetrical versus asymmetrical arrangement of thylakoids reported for the type species $H$. excentricum, and the absence of gas vacuoles are morphological features distinctive of the marine animal associated ITAC101 strain.

The pigment analysis of the strain ITA101 in culture revealed a profile typical of several cyanobacterial species in which chlorophyll-a and phycobiliproteins (phycoerythrin, phycocyanin and allophycocyanin) contribute to the absorption of almost the whole spectrum of visible light (Evangelista et al. 2006). Contrary to most of the cyanobacteria, in which $\beta$-carotene is invariably present and frequently as major carotenoid (HERTZBerg et al. 1971), zeaxanthin was the most abundant followed by $\beta$-cryptoxanthin, another xanthophyll frequent in Oscillatorialean cyanobacteria (AAKERMANN et al. 1992). The carotenoid composition of ITAC 101 is rather peculiar also considering that neoxanthin detected in this strain has been detected mostly in green algae (TAIKAICHI \& MiRAuRo 1998). By dissipating surplus energy, zeaxanthin acts as an essential protective part of the photosynthetic apparatus, though depending on light intensity, varying amounts of zeaxanthin are to be expected (WILHELM et al. 1995).

Although the strain ITAC101 in nature is deep green in color, phycoerythrin was the most abundant pigment in culture. The same phycoerythrin has been possibly purified from the Halomicronema sp. A32DM isolated from rocky shores, that showed absorbance peaks at $562 \mathrm{~nm}$ and fluorescence emission at $580 \mathrm{~nm}$ (PARMAR et

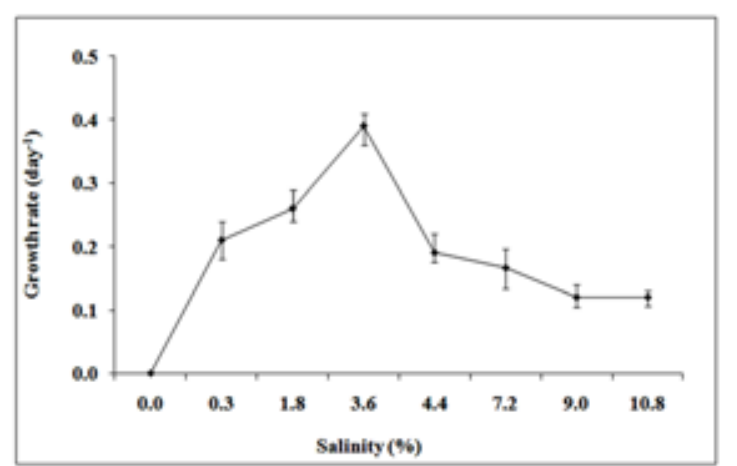

Fig. 3. Growth rates of Halomicronema ITAC101 at different salinity conditions. Symbols are the average of triplicate determination. 


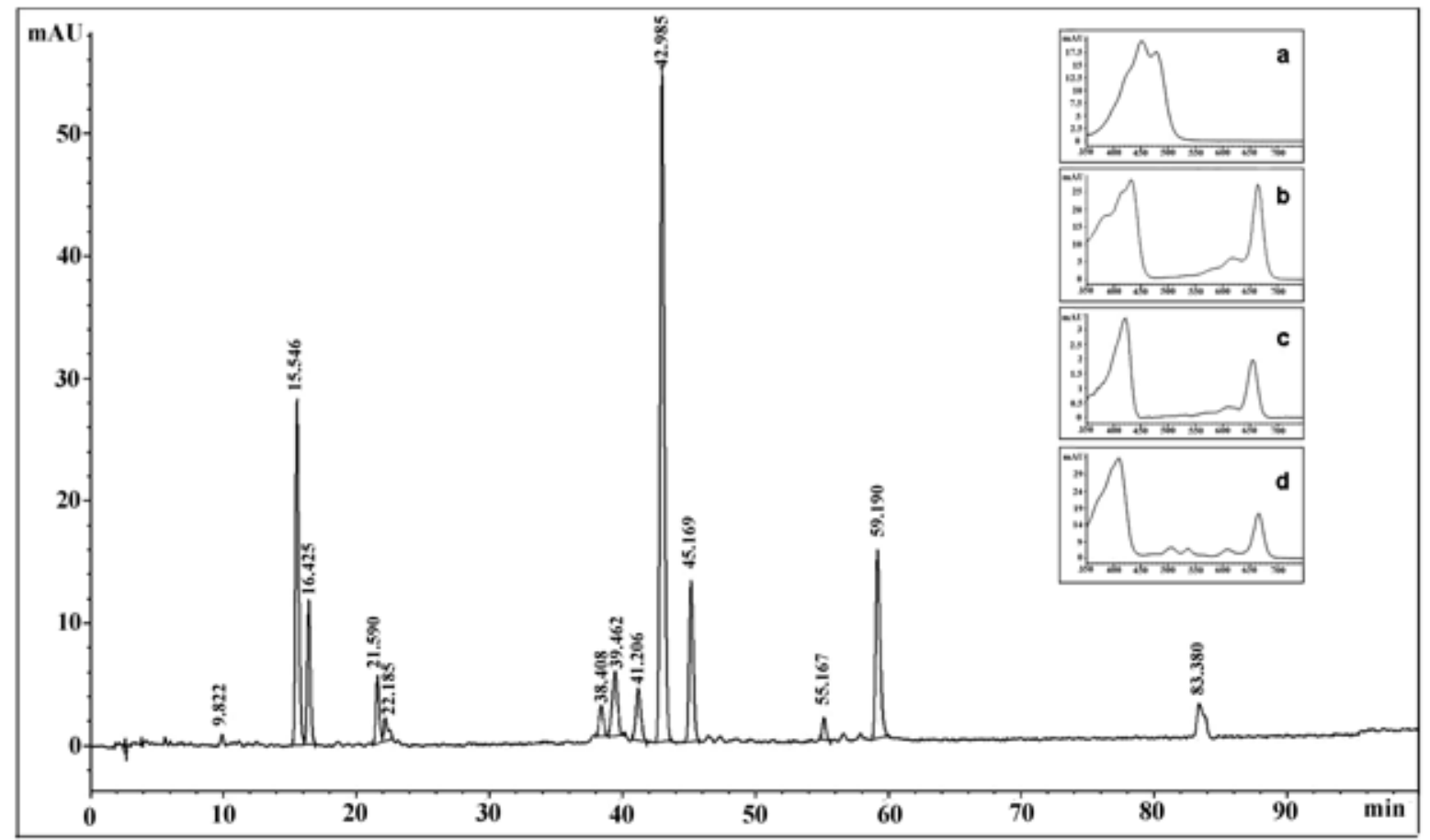

Fig. 4. HPLC chromatogramme of lipophilic pigments of Halomicronema ITAC101. Numbers on the peaks represent, respectively: $1=$ Zeaxanthin $_{(1)} ; 2=$ Zeaxanthin $_{(2)} ; 3=$ Zeaxanthin $_{(3)} ; 4=\beta$ - -hryptoxanthin $_{(1)} ; 5=\beta$ - chryptoxanthin $_{(2)} ; 6=Z$ Zn-chlorophyll- $a_{(1)}$; $7=\mathrm{Mg}$-chlorophyll $-a_{(1)} ; 8=\mathrm{Zn}-$ chlorophyll $-a_{(2)} ; 9=\mathrm{Mg}-$ chlorophyll $-a_{(2)} ; 10=\mathrm{Mg}-$ chlorophyll $-a_{(3)} ; 11=$ Pheophytin- $a ; 12=\beta-$ carotene $_{(1)} ; 13=\beta$ - carotene $_{(2)}$. The inserts show the absorbance spectra of eluted zeaxanthin (a), Mg-chlorophyll-a (b), $\mathrm{Zn}-$ chlorophyll- $a$ (c) and pheophytin- $a$ (d).

al. 2011). In scleractinian corals, deeper bands are formed by cyanobacteria containing $\mathrm{Chl}-a$ and phycobiliproteins (RAPLH et al. 2007). A pale green layer within the skeleton of Goniastrea australensis was dominated by an unidentified endolithic filamentous cyanobacterium extremely shade-adapted and able to efficiently use light to thrive under the optically dense coral tissue that exhibits a strong light attenuation and spectral filtering (RALPH et al. 2007).

Molecular analysis evidenced that the strain Halomicronema ITAC101 possesses a high $(>99 \%)$ sequence identity with Halomicronema sp. Goniastrea-1 at $16 \mathrm{~S}$ rRNA gene level, whereas only $94.8 \%$ similarity with $H$. excentricum. The $99.9 \%$ sequence identity of ITAC101 strain $16 \mathrm{~S}$ rRNA gene with that of Halomicronema sp. Goniastrea-1 is well above the molecular limits for species definition indicated by STACKEBRANDT $\&$ EBERS (2006). On the other hand, match analysis of other Halomicronema 16S rRNA gene sequences of significant length $(>1000 \mathrm{pb})$ at GenBank indicated that these strains generally showed identity $<95 \%$, close to the limit for genus delimitation (STACKEBRANDT \& EBERS 2006). Indeed, identity values between $16 \mathrm{~S}$ rRNA of ITAC 101 strain and those of other thin filamentous cyanobacteria were always below this limit, except 96\% similarity with the strain Leptolyngbya CR L27 (GenBank accession number EF545640) as indicated by bootstrap values and blast analysis (not shown) but unfortunately no morphological and ecological information is available to support a correct taxonomic identification of this strain.

Therefore, according to the ecological, morphological and genetic differences we concluded that strain ITAC101 and strain Goniastrea-1 can be considered as a new phylotype within the genus Halomicronema. This strain resulted well separated phylogenetically, from $H$. excentricum forming a distinct sister clade highly supported in bootstrap and Bayesian analyses, and hence it is described in this work as a new species.

Here we propose the species name Halomicronema metazoicum because of the association with widespread species of marine sponges and corals.

Further studies will be necessary to clarify the degree of association to the sponge and how the same species can live as endolith inside the coral skeleton. One possible explanation might be found in the biological activity exerted by Halomicronema ITAC101 against bacterial 


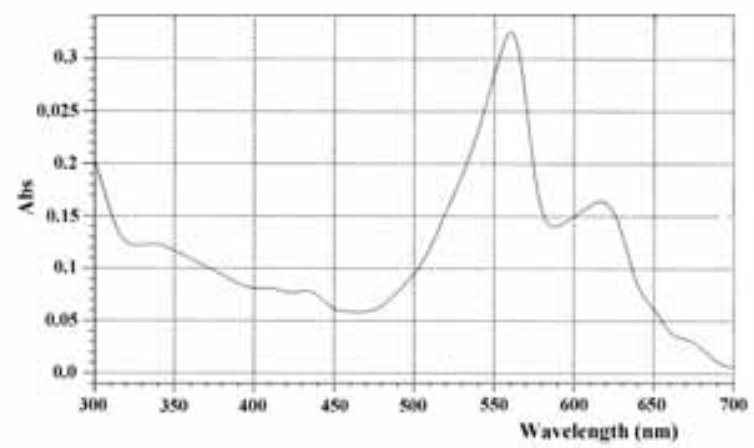

Fig. 5. The UV-visible absorption spectra of crude phycobiliprotein extracts of Halomicronema ITAC101. Major peaks are due the maximum absorption of phycoerythrin at $560 \mathrm{~nm}$ and phycocyanin at $615 \mathrm{~nm}$. Allophycocyanin is visible as the shoulder at $650 \mathrm{~nm}$.

pathogens. Results from studies on corals also suggested that colonization of endolithic algae within the coral skeleton provides beneficial effects on coral photosynthesis in terms of highlight tolerance (YAMAZAKI et al. 2008b).

The literature results also indicate that thin filamentous cyanobacteria of the Halomicronema and Phormidium genera contain a group of opportunistic microorganisms that tend to prevail after perturbations in ecosystems, including oil-tolerant cyanobacteria that dominate the mats immediately after oil spill events (ABED \& GoluBic 2009). H. metazoicum might be one of these organisms able to acclimate to the disturbed conditions of the Gulf of Taranto and possibly the Bisezaki waters in Japan. Further studies may be aimed to investigate the role of this new species similarly to $H$. excentricum in the degradation of oil compounds (ABED \& KÖSTER 2005).

\section{Halomicronema metazoicum CARoppo, Pagli- ara et Albertano sp. nov.}

Diagnosis: tenues filamenta solitaria metazoans adiuncti. Filamenta penitus viridia. Lapsus motility absit et non phototactic filamentis. Vaginae sine colore, firmae, tenues, distinctae. Trichomata leviter constricta melius visibilis ad electrum microscopium. Cellulae apicales sine calyptra. Cellulae 0.8-1.0 $\mu \mathrm{m}$ latae et 3-6 longae. Thylakoidae sunt disposita periphericorum concentricis circum axem longa trichoma. Parce halotolerant et halophilic cyanobacterium.

Habitus. Spongia et corallia.

Collectio conservata deposita in: IAMC-CNR (ITAC101) depositus (coll. Carmela Caroppo, 23.09.1999);

Type species: Halomicronema metazoicum species nova
Description of Halomicronema metazoicum sp. nov.

Thin filamentous marine cyanobacterium associated to metazoans. Filaments and cultures are deep-green in colour. Gliding motility is absent and filaments are not phototactic. Sheath is colourless, firm, distinct and very thin. Trichomes with slight constriction at the crosswalls, better visible in confocal and electron microscopy. The calyptra is present at the top of the apical cell. Cells are $0.8-1.0 \mu \mathrm{m}$ in diameter and 3-6 $\mu \mathrm{m}$ long. Thylakoids are peripheral and concentrically arranged around the long axis of the trichome. Moderately halophilic and halotolerant cyanobacterium. Found as phycobiont of marine sponges in the Mediterranean Sea and scleractinian corals in Japan.

Type strain: ITAC101, isolated from the sponge Petrosia ficiformis sampled in the Northern Ionian Sea (Mediterranean Sea). Deposited and maintained at the Culture Collection of the Coastal Marine Environment, National Research Council, Taranto. GenBank accession number: GU220365.

\section{Acknowledgments}

We would like to thank Alessandro Bellino (Department of Chemistry, University of Salerno, Fisciano (Salerno), Italy) for HPLC pigment analyses.

\section{References}

Aakermann, T.; Skulberg, O.M. \& Liafen-Jensen, S. (1992): A comparison of the carotenoids of strains of Oscillatoria and Spirulina (Cyanobacteria). Biochem. Syst. Ecol. 20: 761-769.

Abed, R.M.M.; Al-Thukair, A. \& DE BeEr, D. (2006): Bacterial diversity of a cyanobacterial mat degrading petroleum compounds at elevated salinities and temperatures. - FEMS Microbiol. Ecol. 57: 290301.

Abed, R.M.M.; Garcia-Pichel, F. \& HernándeZ-Mariné, M. (2002a): Polyphasic characterization of benthic, moderately halophilic, moderately thermophilic cyanobacteria with very thin trichomes and the proposal of Halomicronema excentricum gen. nov., sp. nov. - Arch. Microbiol. 177: 361-370.

Abed, R.M.M. \& Golubic, S. (2009): Selection of oiltolerant cyanobacteria on oil polluted sediments. Algological Studies 130: 69-79.

Abed, R.M.M. \& Köster, J. (2005): The direct role of aerobic heterotrophic bacteria associated with cyanobacteria in the degradation of oil compounds. - Int. Biodet. Biodegr. 55: 29-37.

Abed, R.M.M.; SAfi, N.M.D.; Köster, J.; DE BeER, D.; ElNahhal, Y.; Rullkötter, J. \& Garcia-Pichel, F. 


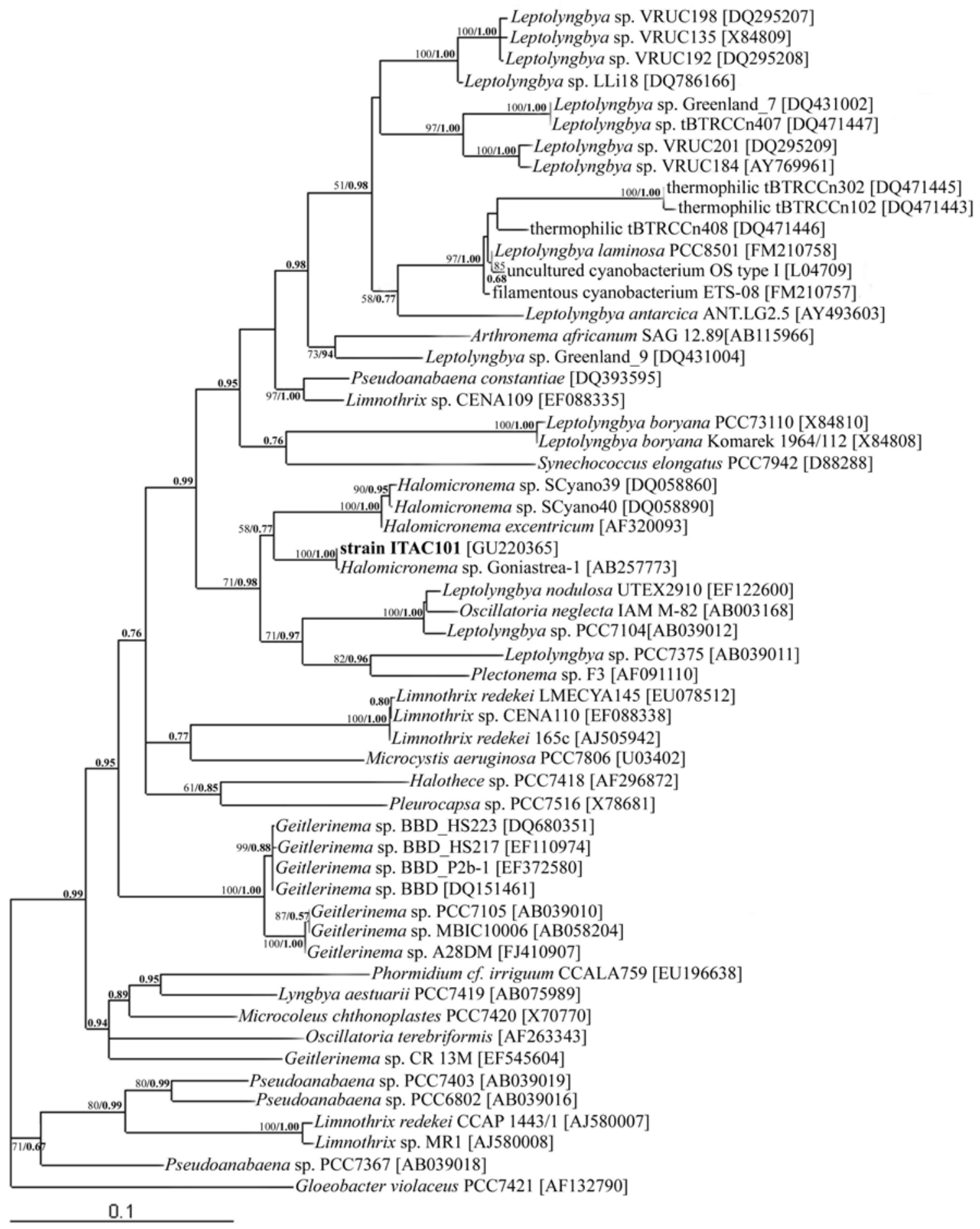

Fig. 6. Phylogenetic tree based on 16S rRNA gene sequences and reconstructed using the maximum-likelihood (ML) analysis. Numbers above branches indicate, in order, the bootstrap value of the ML (as percentages of 1,000 replications, greater than $50 \%$ ) and Bayesian posterior probability (in bold). Strain ITAC101 is indicated in bold, GenBank accession numbers are indicated in brackets. Bar represents 0.1 nucleotide substitutions per site. 
(2002b): Microbial diversity of a heavily polluted microbial mat and its community changes following degradation of petroleum compounds. - Appl. Environ. Microbiol. 68: 1674-1683.

Airs, R.L.; Atkinson, J.E. \& Keely, B.J. (2001): Development and application of a high resolution liquid chromatographic method for the analysis of complex pigment distributions. - J. Chromatog. A 917: 167-177.

Anagnostidis, K. \& Komárek, J. (1988): Modern approach to the classification system of cyanophytes. 5 . Oscillatoriales. - Arch. Hydrobiol./ Algological Studies 80: 327-472.

Bennett, A. \& Bogorad, L. (1972): Properties of subunits and aggregates of blue-green algal biliproteins. Biochemistry 10: 3625-3634.

Bruno, L.; Billi, D.; Bellezza, S. \& Albertano, P. (2009): Cytomorphological and genetic characterization of troglobitic Leptolyngbya strains isolated from Roman hypogea. - Appl. Environ. Microbiol. 75: 608-617.

CARPENTER, E.J. (2002): Marine cyanobacterial symbioses. Biology and environment. - P. Roy. Irish Acad. B 102: $15-18$.

Casamatta, D.A., Johansen, J.R., Vis, M.L. \& Broadwater, S.T. (2005): Molecular and morphological characterization of ten polar and near polar strains within the Oscillatoriales (Cyanobacteria). - J. Phycol. 41: 421-438.

Castenholz, R.W. (1988): Culturing methods for cyanobacteria. - In: ABelson, J. (ed.): Methods in Enzymology: Cyanobacteria 167. - pp. 68-93, Academic Press San Diego, CA, USA.

Castenholz, R.W. \& Waterbury, J.B. (1989): Taxa of the cyanobacteria. - In: Staley, J.T., Bryant, M.P.N. \& Pfennig, J.G. (eds): Bergey's Manual of Systematic Bacteriology 3. - pp. 1727-1728, William \& Wilkins, Baltimore.

Comte, K.; Sabacka, M.; Carre-Mlouka, A.; Elster, J. \& KoMÁREK, J. (2007): Relationships between the Arctic and the Antarctic cyanobacteria; three Phomidiumlike strains evaluated by a polyphasic approach. FEMS Microbiol. Ecol. 59: 366-376.

Diaz, M.C.; Thacker, R.W.; RÜtZler, K. \& Piantoni, C. (2007): Two new haplosclerid sponges from Caribbean Panama with symbiotic filamentous cyanobacteria, and an overview of sponge cyanobacteria associations. - In: Custodio, M.R.; Lôbo-Hajdu, G.; Hajdu, E. \& Muricy, G. (eds): Porifera Research: Biodiversity, Innovation and Sustainability. - pp. 31-39, Museu Nacional, Série Livros 28, Museu, Rio de Janeiro.

Evangelista, V.; Frassanito, A.M.; Passatelli, V.; Barsanti, L. \& Gualtieri, P. (2006): Microspectroscopy of the photosynthetic compartment of algae. - Photochem. Photobiol. 82: 1039-1046.

Feldmann, J. (1933): Sur quelques cyanophycées vivant dans le tissu des éponges de banyules. - Arch. Zool. Exp. Gén. 5: 331-404.

FenICAL, W. (1997): New pharmaceuticals from marine organisms. - Mar. Biotechnol. 15: 339-341.

Fiore, M.F.; MoOn, D.H.; Tsai, S.M.; LeE, H. \& Trevors, J.T. (2000): Miniprep DNA isolation from unicellular and filamentous Cyanobacteria. - J. Microbiol. Meth. 39: 159-169.
Fourçans, A.; García de Oteyza, T.; Wieland, A.; Solé, A.; Diestra, E.; van BleisswiJk, J.; Grimalt, J.O.; Kühl, M.; Esteve, I.; Muyzer, G.; Caumette, P. \& Duran, R. (2004): Characterization of functional bacterial groups in a hypersaline microbial mat community (Salins-de-Giraud, Camargue, France). - FEMS Microbiol. Ecol. 51: 55-70.

Garcia-Pichel, F.; Nübel, U., \& Muyzer, G. (1998): The phylogeny of unicellular, extremely halotolerant cyanobacteria. - Arch. Microbiol. 169: 469-482.

Geitler, L. (1932): Cyanophyceae. In: Rabenhorst, L. (ed): Kryptogamen - Flora von Deutschland, Österreich und der Schweiz 14. - pp. 673-1056, Akademische Verlagsgesellschaft, Leipzig.

Gerçe, B.; Schwartz, T.; Voigt, M.; RÜhle, S.; Kirchen, S.; Putz, A.; Proksch P.; Obst, U.; SyldatK, C. \& Hausmann, R. (2009): Morphological, bacterial, and secondary metabolite changes of Aplysina aerophoba upon long-term maintenance under artificial conditions. -Microb. Ecol. 58: 865-878.

Giovannoni, S.J.; Turner, S.; Olsen, G.J.; Barns, S.; Lane, D.J. \& PACE, N.R. (1988): Evolutionary relationships among cyanobacteria and green chloroplasts. - J. Bacteriol. 170: 3584-3592.

Gkelis, S.; Rajaniemi, P.; Vardaka, E.; Moustaka-Gouni, M.; LaKaras, T. \& Sivonen, K. (2005): Limnothrix redekei (Van Goor) Meffert (Cyanobacteria) strains from Lake Kastoria, Greece form a separate phylogenetic group. - Microb. Ecol. 49: 176-182.

HaygoOd, M.G.; SChMidT, E.W.; Davidson, S.K. \& FAULKNER, D.J. (2000): Microbial symbionts of marine invertebrates: opportunities for microbial biotechnology. - In: BARTLETT, D.H. (ed): Molecular Marine Microbiology 1. - pp. 61-84, Horizon Scientific Press, California.

Hentschel, U.; Hopke, J.; Horn, M.; Friedrich, A.B.; Wagner, M. \& Moore, B.S. (2002): Molecular evidence for a uniform microbial community in sponges from different oceans. - Appl. Environ. Microbiol. 68: 4431-4440.

Hentschel, U.; Schmid, M.; Wagner, M.; Fieseler, L.; Gernert, C. \& HaCKer, J. (2001): Isolation and phylogenetic analysis of bacteria with antimicrobial activities from the Mediterranean sponges Aplysina aerophoba and Aplysina cavernicola. - FEMS Microbiol. Ecol. 35: 305-312.

Hentschel, U.; Usher, K.M. \& TAYLor, M.W. (2006): Marine sponges as microbial fermenters. - FEMS Microbiol. Ecol. 55: 167-177.

Hertzberg, S.; LiaAen-Jensen, S. \& Siegelman, H.W. (1971): Carotenoids of blue-green algae 7 . The carotenoids of further blue-green algae-a chemosystematic contribution. - Phytochemistry 10: 3121-3127.

KANA, T.M. \& GLIBERT, P.M.G. (1987): Effect of irradiances up to $2000 \mu \mathrm{E} \mathrm{m}^{-2} \mathrm{~s}^{-1}$ on marine Synechococcus WH7803-I. Growth, pigmentation and cell composition. - Deep-Sea Res. 34: 479-495.

KomÁreK, J. (2005): The modern classification of Cyanoprokaryotes (Cyanobacteria). - Oceanol. Hydrobiol. Studies 34: 5-17.

Küpper, H.; Seibert, S. \& Parameswaran, A. (2007): Fast sensitive, and inexpensive alternative to analytical pigment HPLC: quantification of chlorophylls and carotenoids in crude extracts by fitting with Gauss peak spectra. - Anal. Chem. 79: 7611-7627. 
Lafi, F.F.; Garson, M.J. \& Fuerst, J.A. (2005): Culturable Bacterial Symbionts Isolated from Two Distinct Sponge Species (Pseudoceratina clavata and Rhabdastrella globostellata) from the Great Barrier Reef Display Similar Phylogenetic Diversity. Microb. Ecol. 50: 213-220.

Lane, D.J.; Pace, B.; Olsen, G.J.; Stahl, D.A.; Sogin, M.L. \& PACE, N.R. (1985): Rapid determination of $16 \mathrm{~s}$ rRNA sequences for phylogenetic analyses. - P. Natl. Acad. Sci. USA 82: 6955-6959.

LARKUM, A.W.D. (1999): The cyanobacteria of coral reefs. - In: Charpy, L. \& Larkum, A.W.D. (eds): Marine Cyanobacteria, Bulletin de I'Institut Oceanographique Monaco, Numero special 19. - pp. 149-167, Musee Oceanographique, Monaco.

Larkum, A.W.D.; Cox, G.C. \& Dibbayawan, T.P. (1988): Prokaryotic algal symbionts of coral reef sponges. - In: Chote, J.H.; Barnes, D.; BorowitzKa, M.A.; Coll, J.C.; Davies, P.J.; Flood, P.; Hatcher, B.G.; Hopley, D.; Hutchings, P.A.; Kinsey, D.; Orme, G.R.; Pichon, M.; Sale, P.F.; Sammarco, P.; Wallace, C.C.; Wilkinson, C.; Wolanski, E. \& Bellwood, O. (eds): Proceedings of the 6th International Coral Reef Symposium Contributed Papers 3. - pp. 163-169, Townsville, Australia.

Lotti, F.; Giovannetti, L.; Margheri, M.C.; Ventura, S. \& Materassi, R. (1996): Diversity of DNA methylation pattern and total DNA restriction pattern in symbiotic Nostoc. - World J. Microbiol. Biotechnol. 12: 3842.

Maniatis, T.; Fritsch, E.F. \& SAmbrook, J. (1982): Molecular Cloning, A Laboratory Manual. - 545 pp., Cold Spring Harbor, New York.

Marquardt, J. \& Palinska, K.A. (2007): Genotypic and phenotypic diversity of cyanobacteria assigned to the genus Phormidium (Oscillatoriales) from different habitats and geographical sites. - Arch. Microbiol. 187: 397-413.

Meeks, J.C. \& Castenholz, R.W. (1971): Growth and photosynthesis in an extreme thermophile Synechococcus lividus (Cyanophyta). - Arch. Mikrobiol. 78: 25-41.

Moore, R.E.; Patterson, G.M.L. \&. Carmichael, W.W. (1988): New Pharmaceuticals From Cultured BlueGreen Algae. - In: Fautin, D.G. (ed.): Biomedical Importance of Marine Organisms 13. - pp. 143-150, Memoirs of the Californian Academy of Science, Californian Academy of Science, San Francisco, CA.

Nübel, U.; Garcia-Pichel, F.; Clavero, E. \& Muyzer, G. (2000): Matching molecular diversity and ecophysiology of benthic cyanobacteria and diatoms in communities along a salinity gradient. - Environ. Microbiol. 2: 217-226.

Pagliara, P. \& Caroppo, C. (2010): A Leptolyngbya species isolated from the sponge Petrosia ficiformis as potential source of novel compounds. - Rapp. Comm. Int. Mer Médit. 39: 392.

Pagliara, P. \& CAroppo, C. (2011): Cytotoxic and antimitotic assessment of aqueous extracts from eight cyanobacterial strains isolated from the marine sponge Petrosia ficiformis. - Toxicon 57: 889-896.

Parmar, A.; Singh, N.K.; Kaushal, A.; Sonawala, S. \& Madamwar, D. (2011): Purification, characterization and comparison of phycoerythrins from three different marine cyanobacterial cultures. - Bioresour. Technol. 102: 1795-1802.

Posada, D. (2008): jModelTest: Phylogenetic Model Averaging. - Mol. Biol. Evol. 25: 1253-1256.

RalPh, P.J.; LaRKum, A.W.D. \& KüHL, M. (2007): Photobiology of endolithic microorganisms in living coral skeletons: 1. Pigmentation, spectral reflectance and variable chlorophyll fluorescence analysis of endoliths in the massive corals Cyphastrea serailia, Porites lutea and Goniastrea australensis. - Mar. Biol. 152: 395-404.

Rippka, R.; Deruelles, J.; Waterbury, J.B.; Herdman, M. \& Stanier, R.Y. (1979): Generic assignments, strain histories and properties of pure cultures of cyanobateria. - J. Gen. Microbiol. 111: 1-61.

Ronquist, F. \& Huelsenbeck, J.P. (2003): MrBayes 3: Bayesian phylogenetic inference under mixed models. - Bioinformatics 19: 1572-1574.

RÜTZLER, K. (1990): Associations between Caribbean sponges and photosynthetic organisms. In: RÜTZLER, K. (ed.): New Perspectives in Sponge Biology. - pp. 455-466, Smithsonian Institute Press, Washington, D.C.

SAmbrook, J. \& Russel, D.W. (2001): Molecular Cloning: A Laboratory Manual, 3rd edn. - pp. 631-632, Cold Spring Harbour Laboratory Press, Cold Spring Harbour, New York.

Sivonen, K. \& BöRnER, T. (2008): Bioactive compounds produced by cyanobacteria. In: Herraro, A. \& Flores, E. (eds): The cyanobacteria: Molecular Biology, Genomics and Evolution. - pp. 159-197, Caister Academic Press, Norfolk.

Stackebrandt, E. \& EBers, J. (2006): Taxonomic parameters revisited: tarnished gold standards. - Microbiol. Today 33: 152-155.

Steindler, L.; Huchon, D.; Avni, A. \& Ilan, M. (2005): 16S rRNAphylogeny of sponge-associated cyanobacteria. - Appl. Environ. Microbiol. 17: 385-396.

Swofford, D.L. (2001): PAUP_Phylogenetic Analysis Using Parsimony (and Other Methods). Version 4. Sinauer Associates, Sunderland, MA.

TAKaIChI, S., \& Mirauro, M. (1998): Distribution and geometric isomerism of neoxanthin in oxygenic phototrophs: 9'-Cis, a sole molecular form. - Plant Cell. Physiol. 39: 968-977.

Taylor, M.W.; Thacker, R.W. \& Hentschel, U. (2007): Genetics: evolutionary insights from sponges. Science 316: 1854-1855.

Thacker, R.W. \& Starnes, S. (2003): Host specificity of the symbiotic cyanobacterium Oscillatoria spongeliae in marine sponges, Dysidea spp. - Mar. Biol. 142: 643-648.

Usher, K.M. (2008): The ecology and phylogeny of cyanobacterial symbionts in sponges. - Mar. Ecol. 29: 178-192.

Usher, K.M.; Fromont, J.; Sutton, D.C. \& Toze, S. (2004): The biogeography and phylogeny of unicellular cyanobacterial symbionts in selected sponges from Australia and the Mediterranean. - Microb. Ecol. 48: 167-177.

Webb, V.L. \& MaAs, E.W. (2002): Sequence analysis of 16S rRNA of cyanobacteria associated with the marine sponge Mycale (Carmia) hentscheli. - FEMS Microbiol. Lett. 207: 43-47.

Wilhelm, C.; Volkmar, C.; Lohmann, C.; Becker, A. \& Meyer, M. (1995): The HPLC-aided pigment 
analysis of phytoplankton cells as a powerful tool in water quality control. - J. Water SRT-Aqua 44: 132-141.

Wilkinson, C.R. (1992): Symbiotic interactions between marine sponges and algae. - In: ReISSER, W. (ed.): Algae and Symbiosis: Plants, Animals, Fungi, Viruses. Interactions explored. - pp. 112-151, Biopress, England.

Wilmotte, A. (1994): Molecular evolution and taxonomy of the cyanobacteria. In: Bryant D.A. (ed): The Molecular Biology of the Cyanobacteria. - pp. 1-25, Kluwer, Dordrecht.

YAMAZAKI, S.S.; NAKAMURA, T. \& YAMASAKI, H. (2006): Cyanobacterium Halomicronema sp. colonized within the skeleton of the reef-building coral Goniastrea aspera. - Plant Cell. Physiol. Suppl. 47: 581-581.

YAMAZAKI, S.S.; NaKamuRa, T.; Yuen, Y.S. \& YAmasaKi, H. (2008a): Reef-building coral Goniastrea aspera harbour a novel filamentous cyanobacterium in their skeleton. Proceedings of the $11^{\text {th }}$ International Coral Reef Symposium. - pp. 265-268, Ft. Lauderdale, Florida.

YAMAZAKI, S.S.; NaKamURA, T. \& YAMASAKI, H. (2008b): Photoprotective role of endolithic algae colonized in coral skeleton for the host photosynthesis. - In: Allen, J.F.; Gantt, E.; Golbeck, J.H. \& Osmond, B. (eds): Photosynthesis. Energy from the Sun: 14th International Congress on Photosynthesis. - pp. 1391-1395, Springer, Netherlands.

Zhu, P.; LI, Q. \& Wang, G. (2008): Unique microbial signatures of the alien Hawaiian marine sponge Suberites zeteki. - Microb. Ecol. 55: 406-414.

(C) Czech Phycological Society (2012)

Received July 17, 2011

Accepted September 11, 2011

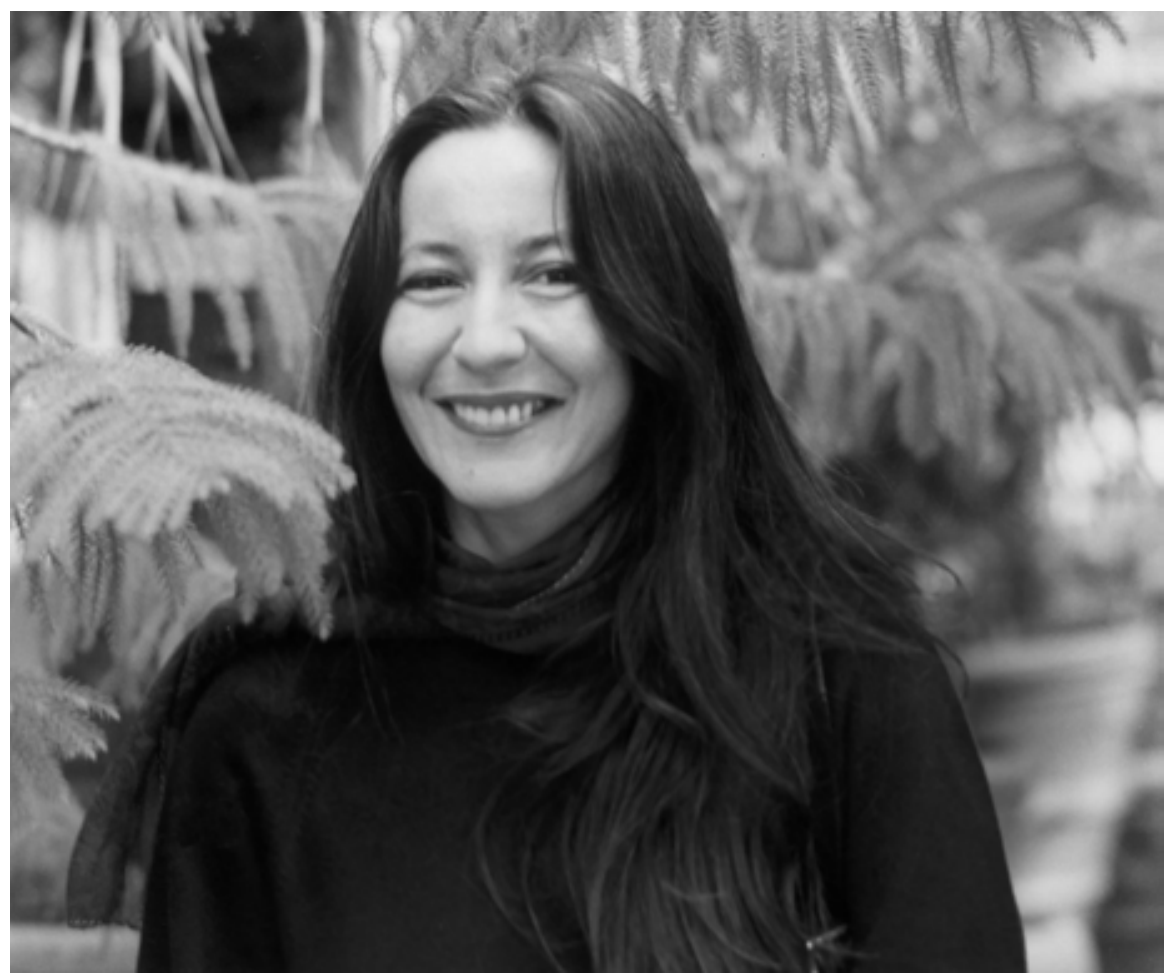

In memory of Patrizia Beatrice Albertano (Sept 1952-Mar 2012), the field of phycology has lost a great scholar and the people who knew and worked with her have lost a great mentor and friend. She left us so much to keep in mind and heart. 